\title{
AN APPROACH TO ACHIEVE THERMAL COMFORT AND SAVE ENERGY IN HERITAGE BUILDINGS USING DIFFERENT OPERATING PATTERNS
}

\author{
REHAB M. AHMAD ${ }^{1,3}$, ZEYAD EL-SAYED ${ }^{2}$, DINA TAHA ${ }^{2}$, HASSAN FATH $^{1} \&$ HATEM MAHMOUD $^{1}$ \\ ${ }^{1}$ Egypt-Japan University of Science \& Technology (E-JUST), Egypt. \\ ${ }^{2}$ Alexandria University (AU), Egypt. \\ ${ }^{3}$ Assiut University, Egypt.
}

\begin{abstract}
The effective utilization of natural ventilation in heritage buildings could save a significant rate of electrical energy, as the airflow pattern affects interior comfort conditions; achieving users' thermal comfort counts as an added value. This study aims to promote an approach in the form of a design strategy for a developed optimal annual operating schedule for heritage buildings, targeting the best operating pattern/s for each month. The study was carried out for a typical heritage building in the central district of Alexandria city (a typical Mediterranean Basin city), Egypt, for improving energy efficiency while achieving users' thermal comfort. The paper adopted a simulation methodology for conducting energy and thermal comfort analyses using DesignBuilder simulation software. The approach was applied to a south-oriented room of the selected residential heritage building, which is the most affected orientation in the temperate-humid (slightly warmer) climate. The developed operating patterns included closed and opened windows, controlled natural ventilation, and HVAC system for cooling and heating with different temperature setpoints. The results showed that using the developed optimal annual operating schedule can save up to $47 \%$ of the total cooling and heating electrical energy annually, while achieving 365 thermally comfortable days a year, including 177 days when only natural ventilation operating patterns are used. The study revealed the importance of considering the optimal operating patterns schedule as an approach to improve the environmental performance of heritage buildings. Also, the optimal annual operating schedule resulted in an adjusted base-case that can be used for evaluating the retrofitting scenarios for south-oriented, energy-efficient heritage buildings in temperate-humid climate. Keywords: energy efficiency, heritage buildings, natural ventilation, thermal comfort.
\end{abstract}

\section{INTRODUCTION}

Energy and buildings are responsible for $60 \%$ and $40 \%$ of the greenhouse gases, respectively, which significantly contribute to climate change [1,2]. 'Egypt vision 2030' is a sustainable development strategy (SDS) that was initiated in 2016; one of its goals and energy sector requirements is to maximize and efficiently utilize the renewable resources to enhance economic growth [3]. Meanwhile, there is significant potential to save energy and enhance occupants' health in residential buildings when using natural ventilation [4] that should be adequately utilized; otherwise, it will result in an increase in the $\mathrm{CO}_{2}$ concentrations and a low indoor air quality [5].

In the MENA region, occupants' comfort and energy conservation can be efficiently improved through using natural ventilation instead of mechanical ventilation [6]. In Bolzano, Italy, Exner et al. analyzed the renovation strategies in a heritage building, and the results showed that applying natural ventilation strategies, such as the mechanical operation of windows, should be investigated carefully to improve indoor air quality and decrease energy consumption [5]. While Thravalou et al. [7] experimented the effect of natural ventilation (daytime, night-time, and all day) on the thermal performance of heritage buildings in Nicosia, Cyprus, the results showed that night natural ventilation is an effective cooling strategy. Moreover, Nunes de Freitas and Guedes [8] addressed the occupants' behavior in controlling windows and how it 
can be environmentally controlled to improve heritage building thermal performance in Portugal. This study revealed that opening windows is an adaptive action by users that could improve thermal comfort while decreasing the use of mechanical systems. To our knowledge, no prior studies in Egypt have examined or quantified the impact of applying the operation patterns schedule on the thermal performance and energy efficiency of heritage buildings.

Egypt is located in a relatively hot climate zone; therefore, thermal comfort is of real need in the summer months [9]. In order to achieve indoor thermal comfort in vernacular buildings, passive cooling and natural ventilation have been considered as the leading traditional methods [10]. Using natural ventilation in buildings can have a significant effect on saving energy. Still, it has to be used carefully to achieve users' thermal comfort as it might result in closing the windows and dependence only on HVAC systems, which consume more energy and may lead to users' thermal discomfort. All the above raises two questions: How many days can natural ventilation be used to reduce electrical energy consumption while achieving thermal comfort? And, how can the spaces be operated to improve its thermal performance, save energy, and achieve users' thermal comfort at the same time?

Therefore, this study seeks to promote an approach in the shape of a design strategy for a developed optimal annual operating schedule for heritage buildings targeting the best operating pattern/s for each month, in order to achieve occupants' thermal comfort while saving cooling and heating electrical energy in Alexandria, Egypt. The study also aims at quantifying the contribution of each operating pattern in improving the environmental performance in heritage buildings.

\section{METHODOLOGY}

The methodology contains three main parts. The first part is the base-case and its properties that were collected by surveying the case study site and collecting the required data for the digital simulation. The second part is modeling the base-case in DesignBuilder simulation software and then experimenting the different operating patterns through three phases: the first phase, base-case with closed windows all day; the second phase, using natural ventilation all day and then controlling with a temperature setpoint; and the third phase, operating the most commonly used HVAC system for cooling and heating and then changing the cooling temperature setpoint. Each phase was selected based on the PMV results of the previous phase till achieving thermal comfort in all days of the year. Finally, the obtained results were analyzed to develop the optimal annual operating schedule that were applied to a room to examine its feasibility in achieving thermal comfort and saving energy. However, this methodology can be applied typically on the whole building to develop the optimal annual operating schedule of its different rooms.

\subsection{Base-case}

The selected heritage building for this study is the Cordahi building, a residential heritage building located in the central district of Alexandria. It is a part of the Cordahi complex that was built between 1921 and 1928. Its south-eastern façade overlooks one of Alexandria's famous streets (Fouad Street), as shown in Fig. 1. The building's rectangular floor plan is $1000 \mathrm{~m}^{2}$ with openings (balconies and windows) in all four facades. The base-case is a south-oriented room on the third floor of the Cordahi building, which is the most affected orientation in the temperate-humid climate as it receives the highest solar radiation and consumes the most cooling energy consumption, as shown in Fig. 2. 


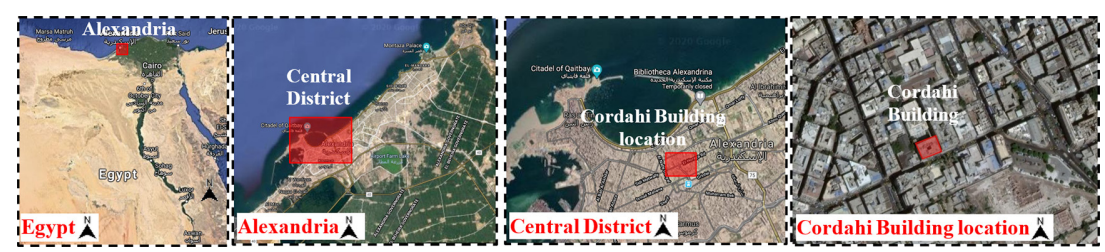

Figure 1: Location of Cordahi building in Alexandria, Egypt. (Source: www.google.com.eg/ maps).
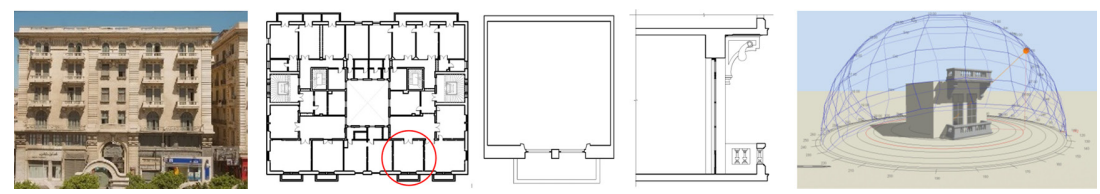

Figure 2: Left to right: Cordahi building Façade (Source: www.sigmaproperties.net), thirdfloor plan, selected room base-case (plan, cross-section, and shot from simulation).

\subsection{Simulation}

The base-case ceiling, floor, and internal walls are considered adiabatic, except the external wall; the room properties and simulation settings are shown in Table 1, and the tested operating patterns of this study are shown in Table 2. The used weather file is a TMYx file that is generated based on 15 years of continuously measured data from 2003 till 2017.

DesignBuilder simulation software is used to calculate the following:

1. Thermal comfort (Fanger PMV index): daily average PMV values (comparing the PMV results with ASHRAE PMV thermal sensation scale with Standard 55-2017 levels [11], as shown in Table 3)

Table 1: Properties and simulation settings of the tested room in the Cordahi building.

Weather file EGY_IK_Alexandria-Nozha.Intl.AP.623180_TMYx.2003-2017

Room dimen- Floor: $5.5 \mathrm{~m} \times 5.5 \mathrm{~m}$, height: $4.1 \mathrm{~m}$, balcony door height: $3.4 \mathrm{~m}$ sions

External wall $\quad 0.02 \mathrm{~m}$ plaster $+0.58 \mathrm{~m}$ limestone, hard $+0.03 \mathrm{~m}(\mathrm{U}$-value $=1.72 \mathrm{~W} /$ $\mathrm{m}^{2} \mathrm{k}$ )

Internal wall Adiabatic $(0.02 \mathrm{~m}$ plaster $+0.15 \mathrm{~m}$ limestone, hard $+0.02 \mathrm{~m}$ plaster $)$

Floor and ceil- $\quad$ Adiabatic $(0.1 \mathrm{~m}$ cast concrete)

ing

Glass

Single clear $-6 \mathrm{~mm}\left(\mathrm{U}\right.$-value $\left.=6.12 \mathrm{~W} / \mathrm{m}^{2} \mathrm{k}, \mathrm{SHGC}=0.81, \mathrm{VT}=0.88\right)$

WWR $36 \%$

HVAC Template: split or multi-split system with ventilation Cooling, heating, and natural ventilation schedule: on 24/7

Occupancy (Occupants: residents) (activity: $1 \mathrm{MET})($ clothing [Clo]: winter $=1$ / summer $=0.5)($ Schedule: residential occ $)\left(\right.$ density [people $\left.\left./ \mathrm{m}^{2}\right]: 0.1\right)$ 
Table 2: The tested operating patterns of this study.

\begin{tabular}{ll}
\hline Base-case & Windows are closed all day \\
NV 24/7 & Natural ventilation, windows are open all day \\
NV setpoint & Natural ventilation with setpoint control (min. temperature setpoint $22^{\circ} \mathrm{C}$ ) \\
HVAC 1 & Cooling (temperature setpoint $26^{\circ} \mathrm{C}$ ) + heating (temperature setpoint $22^{\circ} \mathrm{C}$ ) \\
HVAC 2 & Cooling (temperature setpoint $\left.25^{\circ} \mathrm{C}\right)+$ heating (temperature setpoint $22^{\circ} \mathrm{C}$ ) \\
HVAC 3 & Cooling (temperature setpoint $\left.24^{\circ} \mathrm{C}\right)+$ heating (temperature setpoint $22^{\circ} \mathrm{C}$ ) \\
HVAC 4 & Cooling (temperature setpoint $\left.23^{\circ} \mathrm{C}\right)+$ heating (temperature setpoint $22^{\circ} \mathrm{C}$ ) \\
HVAC 5 & Cooling (temperature setpoint $\left.22^{\circ} \mathrm{C}\right)+$ heating (temperature setpoint $22^{\circ} \mathrm{C}$ ) \\
HVAC 6 & Cooling (temperature setpoint $21^{\circ} \mathrm{C}$ ) + heating (temperature setpoint $21^{\circ} \mathrm{C}$ ) \\
\hline
\end{tabular}

Table 3: ASHRAE PMV thermal sensation scale with Standard 55-2017 levels.

\begin{tabular}{llllllllll}
\hline $\begin{array}{l}\text { ASHRAE } \\
\text { PMV } \\
\text { index }\end{array}$ & $\begin{array}{l}\text { Thermal } \\
\text { sensation }\end{array}$ & Cold & Cool & $\begin{array}{l}\text { Slightly } \\
\text { cool }\end{array}$ & $\begin{array}{l}\text { Neutral } \\
\text { (comfort- } \\
\text { able) }\end{array}$ & $\begin{array}{l}\text { Slightly } \\
\text { warm }\end{array}$ & Warm Hot \\
& Value & $-3<-2$ & $-2<-1$ & $-1<-0.5$ & $-0.5:+0.5$ & $+0.5>+1$ & $+1>+2$ & $+2\rangle+3$ \\
& & & & & & & & &
\end{tabular}

2. Indoor operative air temperature (OPT; ${ }^{\circ} \mathrm{C}$, daily average)

3. Relative humidity (RH; \%, daily average)

4. Cooling and heating electricity consumption ( $\mathrm{kW} \mathrm{h}$, monthly and annually)

\section{RESULTS AND DISCUSSION}

This section is divided into four parts: thermal comfort, OPT and RH, cooling and heating electricity consumption, and developing the optimal annual operating schedule.

\subsection{Thermal comfort}

The base-case has only 36 days that have accepted daily average PMV values in the months January, February, April, and May, when the users feel neutral; the remaining days of the year, they either feel slightly warm, warm, or hot with PMV values higher than 3 from July till November. The number of thermally comfortable days increases when using NV 24/7 to 65 days in the months March till June, September, November, and December. Unlike the base-case, in the remaining days of the year, the users started feeling slightly cool, cool, or cold in the winter months, besides feeling slightly warm, warm, or hot, in the summer months, as shown in Fig. 3.

The NV setpoint operating pattern has a minimum temperature setpoint control where windows are open when the inside air temperature is higher than the minimum temperature setpoint $\left(22^{\circ} \mathrm{C}\right)$ and the outside air temperature at the same time to reduce the inside air temperature (natural cooling). A higher number of days that have accepted daily average PMV values (166 days) in 9 months (January till June, September, November, and December) was achieved, as shown in Fig. 3 and Table 4. In order to find the reason behind the higher number 


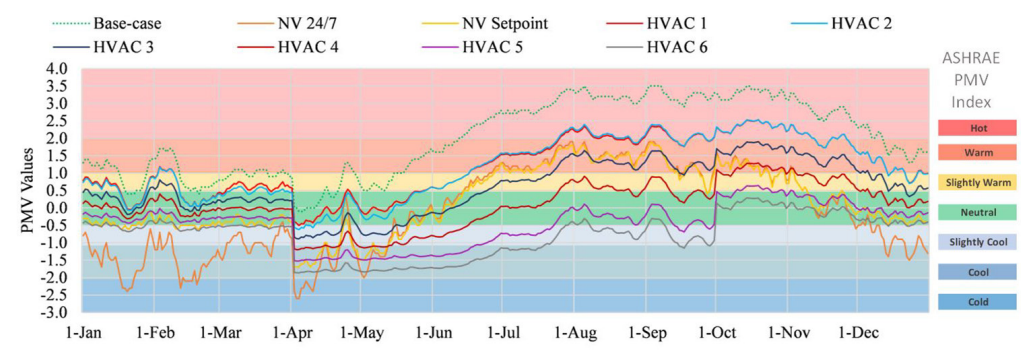

Figure 3: Chart showing the daily average PMV values of the different operating patterns with an indication of the ASHRAE PMV index thermal sensation levels.

Table 4: Number of thermally comfortable days monthly and annually for the different operating patterns.

\begin{tabular}{|c|c|c|c|c|c|c|c|c|c|c|c|c|c|}
\hline $\begin{array}{l}\text { Month } \\
\text { Operat- } \\
\text { ing } \\
\text { pattern }\end{array}$ & 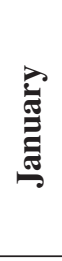 & 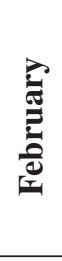 & $\frac{\pi}{2}$ & $\frac{7}{2}$ & $\sum^{3}$ & $\stackrel{\mathscr{\Xi}}{\Xi}$ & 坣 & 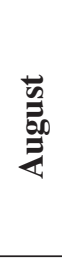 & $\frac{\grave{d}}{\text { है }}$ & 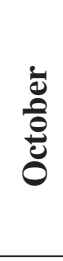 & 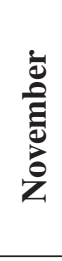 & 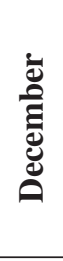 & हैँ \\
\hline Base-case & 8 & 4 & - & 19 & 5 & - & - & - & - & - & - & - & 36 \\
\hline NV 24/7 & - & - & 2 & 4 & 13 & 14 & - & - & 2 & - & 22 & 8 & 65 \\
\hline $\begin{array}{l}\text { NV set- } \\
\text { point }\end{array}$ & 27 & 24 & 30 & 3 & 10 & 16 & - & - & 2 & - & 22 & 31 & 165 \\
\hline HVAC 1 & 12 & 17 & 8 & 29 & 29 & - & - & - & - & - & - & - & 95 \\
\hline HVAC 2 & 13 & 17 & 20 & 24 & 29 & - & - & - & - & - & - & - & 103 \\
\hline HVAC 3 & 29 & 20 & 31 & 8 & 17 & 24 & - & - & - & - & - & 7 & 136 \\
\hline HVAC 4 & 31 & 28 & 31 & 1 & - & 16 & 25 & 12 & 20 & - & - & 30 & 194 \\
\hline HVAC 5 & 31 & 28 & 31 & 1 & - & - & 9 & 31 & 22 & 21 & 30 & 31 & 235 \\
\hline HVAC 6 & 19 & 11 & 22 & 1 & - & - & 4 & 7 & 8 & 31 & 30 & 31 & 164 \\
\hline
\end{tabular}

of thermally comfortable days when using natural ventilation with temperature setpoint control, a comparison has been made between hourly PMV values of base-case, NV 24/7, and NV setpoint for the 15th day of each month. An example is presented in Fig. 4 that shows the hourly PMV values for the 15th of June; its average daily PMV values are 2.1, 0.6, and 0.5 for the base-case, NV 24/7, and NV setpoint, respectively. The results showed that the average daily PMV values do not accurately represent the 24 hours of the day with accepted daily average PMV values. However, using the NV setpoint, operating pattern can have a positive effect on achieving an average daily accepted PMV value; for almost 11 hours (9:30 hours till 20:00 hours) of this day (the 15th of June), the user feels slightly warm. Therefore, it is essential to assure the average daily PMV results by checking either the hourly or sub-hourly PMV values, or discomfort hours (winter, summer, or all clothing) of the tested day/s.

Operating the HVAC system for cooling and heating with HVAC 1, which has temperature setpoints $26^{\circ} \mathrm{C}$ for cooling and $22^{\circ} \mathrm{C}$ for heating, has only 95 days that have acceptable daily 


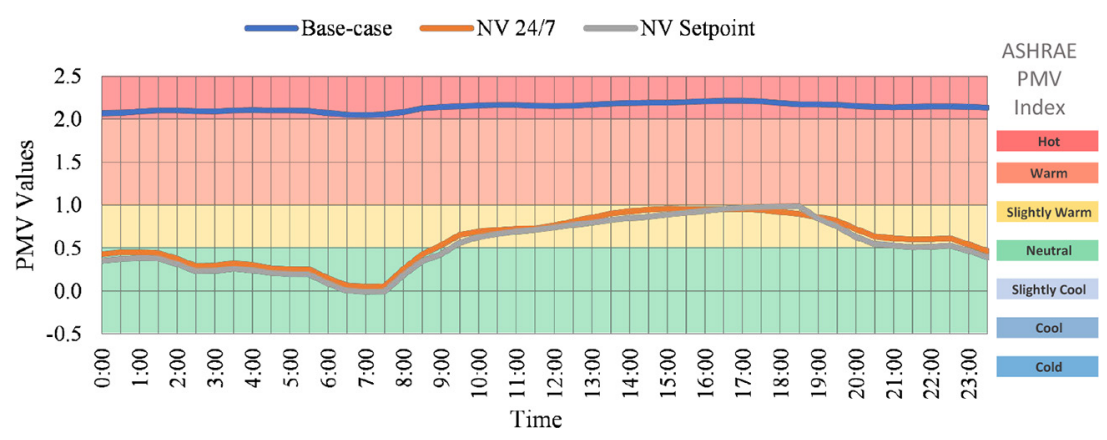

Figure 4: Chart showing a comparison between the base-case, NV 24/7, and NV setpoint hourly PMV values on the 15 th of June.

average PMV values in January till May. The remaining days of the year have average daily PMV values $>0.5$, and to achieve more thermally comfortable days, the cooling temperature setpoint was first dropped to $22^{\circ} \mathrm{C}$ (HVAC 5). Using HVAC 5 increased the number of days that have acceptable daily average PMV values in all months except May and June to 235; meanwhile, some of the remaining days in months June till October required a lower cooling temperature setpoint, while other days required a higher one. In order to achieve more accepted PMV values, the cooling temperature setpoint was reduced to $21^{\circ} \mathrm{C}$ (HVAC 6) and then increased to $24^{\circ} \mathrm{C}$ (HVAC 3 ). In HVAC 6, there are a total of 164 thermally comfortable days with 4, 7, 8, and 31 days in July, August, September, and October, respectively.

While in HVAC 3, 136 thermally comfortable days are achieved in the months December till June, with 24 days in June only with no days from July till November. These 24 days have discomfort hours ranging between 10 and 24 hours a day; therefore, HVAC 3 is not accepted as one of the operating patterns in the optimal annual operating schedule. The remaining days in the months July and August till October have average daily PMV values $>0.5$, and to achieve more accepted PMV values, the cooling temperature setpoint was reduced to $23^{\circ} \mathrm{C}$ (HVAC 4). In HVAC 4, a total of 194 thermally comfortable days was achieved, with 9, 31, 22, and 21 days in July, August, September, and October, respectively. The numbers of the monthly and annually thermally comfortable days using the same operating pattern in the whole year are shown in Table 4. HVAC 5 operating pattern achieves the highest number of thermally comfortable days (235) a year, while the base-case has the lowest number of days (36) a year.

\subsection{OPT and RH}

\subsubsection{Operative air temperature}

According to ASHRAE Standard 55-2017 [11] concerned with thermal comfort, the recommended indoor OPT range for residential buildings is between $19.4^{\circ} \mathrm{C}$ and $27.8^{\circ} \mathrm{C}$, which is marked as horizontal black dashed lines in Fig. 5. In the base-case, the daily average OPT ranges between $25^{\circ} \mathrm{C}$ and $34^{\circ} \mathrm{C}$ in the whole year; these are the highest temperatures in all the operating patterns. Comparing these values with the outside dry-bulb temperature, closing the windows keeps the heat that comes from the sun, which leads to increasing the indoor OPT to the comfort level in the winter months and above it in the summer months.

However, in the NV 24/7, the fluctuation in the OPT is similar to the outside dry-bulb with a difference that ranges between $1{ }^{\circ} \mathrm{C}$ and $6^{\circ} \mathrm{C}$, while in the NV setpoint operating pattern, 


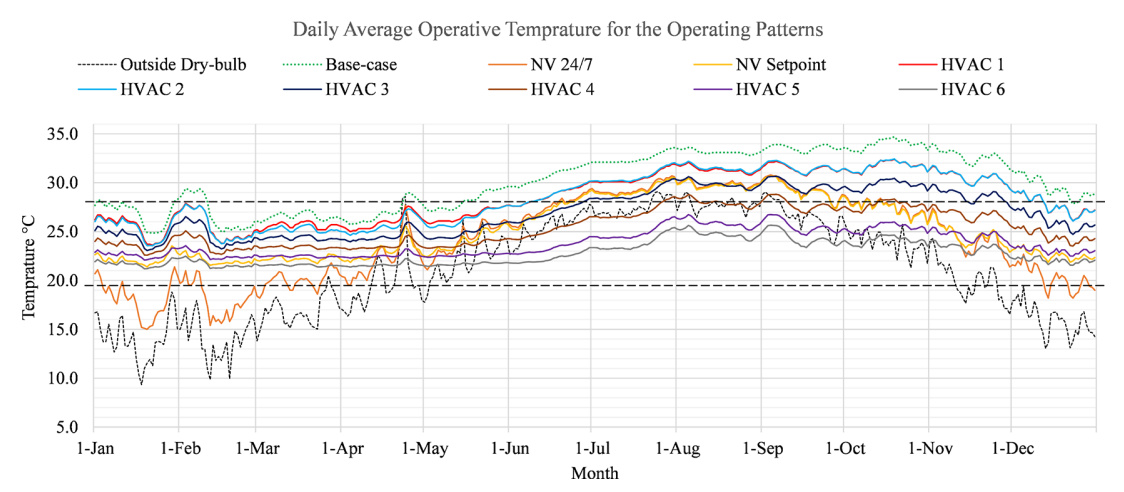

Figure 5: Chart showing the daily average indoor operative temperature for the different operating patterns.

controlling the natural ventilation has a positive effect on the indoor OPT in the winter months, which lies between the base-case and NV 24/7 lines and ranges between $22^{\circ} \mathrm{C}$ and $24^{\circ} \mathrm{C}$ with stability in the indoor temperature level; meanwhile, in the summer months, it has almost the same range as the NV 24/7. On the other hand, when using an HVAC system with different cooling temperature setpoints, lowering the temperature setpoint results in lowering the indoor OPT with around $0.5^{\circ} \mathrm{C}$ difference in the winter months and $2{ }^{\circ} \mathrm{C}$ difference in the summer months for HVAC 2-6, except HVAC 1 and 2 that are almost the same in the whole year. It is also noticed that in the summer months, HVAC 1-3 failed to decrease the indoor OPT to the acceptable level, as shown in Fig. 5.

\subsubsection{Relative humidity}

According to ASHRAE Standard 62.1-2016 [12], concerned with ventilation for acceptable indoor air quality in occupied spaces, the recommended RH ratio is less than $65 \%$, which is marked as horizontal black dashed line in Fig. 6. The daily average RH ratios of all operating patterns have a close range of values in the winter months; this range of values increases in the summer months. The base-case has the highest ratios of the daily average $\mathrm{RH}$ from March till November, with $93 \%$ being the highest value in August and almost all these values being higher than $65 \%$. Using NV 24/7 or NV setpoint has the same effect (with small differences) on reducing the RH by around 10\%:28\%.

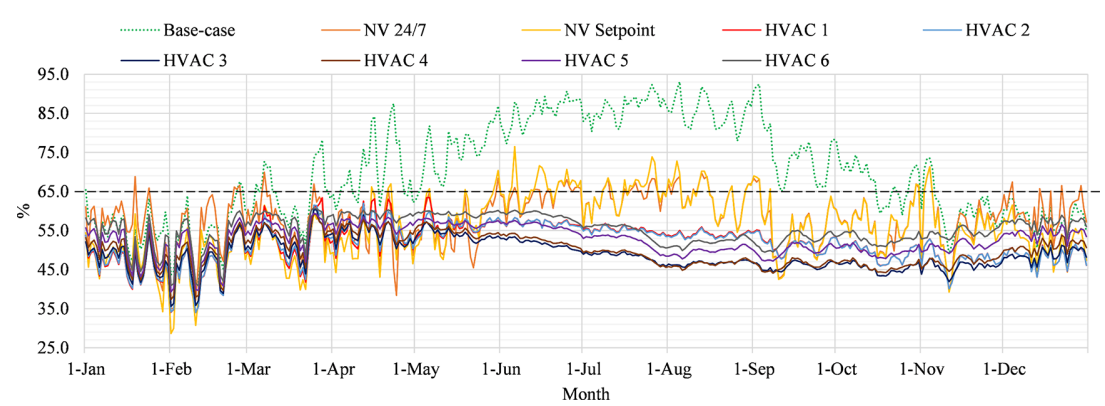

Figure 6: Chart showing the daily average relative humidity for the different operating patterns. 
As shown in Fig. 6, from May till November, using the HVAC system results in a more stable daily average RH ratio line compared with the base-case and NV operating patterns that have a fluctuating daily average RH ratio line. HVAC 1, 2 and HVAC 3, 4 have almost the same values with small differences, while HVAC 6 is higher than HVAC 5 by around $3 \%$ with the same daily average $\mathrm{RH}$ ratio line.

\subsection{Cooling and heating electricity consumption}

The tested HVAC cooling temperature setpoints to find out the impact of reduction of only $1^{\circ} \mathrm{C}$ on electricity consumption are from $26^{\circ} \mathrm{C}$ to $21^{\circ} \mathrm{C}$. The highest annual electricity consumption is $2961 \mathrm{~kW} \mathrm{~h}$ when using HVAC 6 operating pattern, which has the lowest cooling temperature setpoint $\left(21^{\circ} \mathrm{C}\right)$. The highest four monthly electricity consumption values are for the months July, August, September, and October that have close values $(349,350,335$, and $342 \mathrm{~kW}$ h, respectively), as shown in Fig. 7 and Table 5. The lowest two annual electricity consumption values (688 and $722 \mathrm{~kW} \mathrm{~h}$ ) are for HVAC 1 and 2, respectively, which have close monthly values, especially in the months June till December.

Lowering the cooling temperature setpoint by $1^{\circ} \mathrm{C}$ at a time increases the value of electricity consumption gradually, especially in the summer months. HVAC 1, 2, 3, 4, 5, and 6 have annual electricity consumption of $688,722,1420,2015,2600$, and $2961 \mathrm{~kW} \mathrm{~h}$, respectively, with a total annual rise of $34,698,595,587$, and $361 \mathrm{~kW} \mathrm{~h}$ for each $1^{\circ} \mathrm{C}$ decrease in the HVAC cooling temperature setpoint.

On the other hand, there is no heating electricity consumption for HVAC 1 and 2 operating patterns, while HVAC $3,4,5$, and 6 have a little annual heating electricity consumption at 0.3 , 1.7. 8.5, and $3.3 \mathrm{~kW} \mathrm{~h}$, respectively. The reason that HVAC 6 has a lower annual heating electricity consumption than HVAC 5 is that HVAC 6 has a lower heating temperature setpoint of $21^{\circ} \mathrm{C}$. Decreasing the HVAC cooling setpoint lower than $25^{\circ} \mathrm{C}$ results in a decrease in the indoor temperature, which leads to operating the heating system. The low heating electricity consumption is because the room windows' orientation is south-east, which receives solar radiation more than other orientations. Another reason is the thickness of the external wall $(58 \mathrm{~cm})$, which acts as an insulation that keeps the heat inside the room longer than the spaces with lower wall thickness.

\subsection{Developing the optimal annual operating schedule}

The optimal annual operating schedule is based on the results of the thermally comfortable days and the lowest cooling and heating electricity consumption. In order to achieve thermal

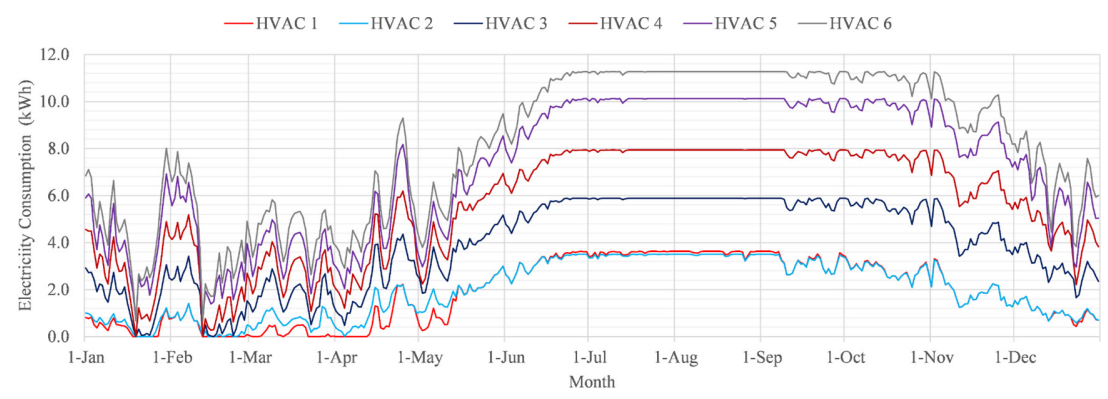

Figure 7: Chart showing the daily electricity consumption for HVAC operating patterns. 


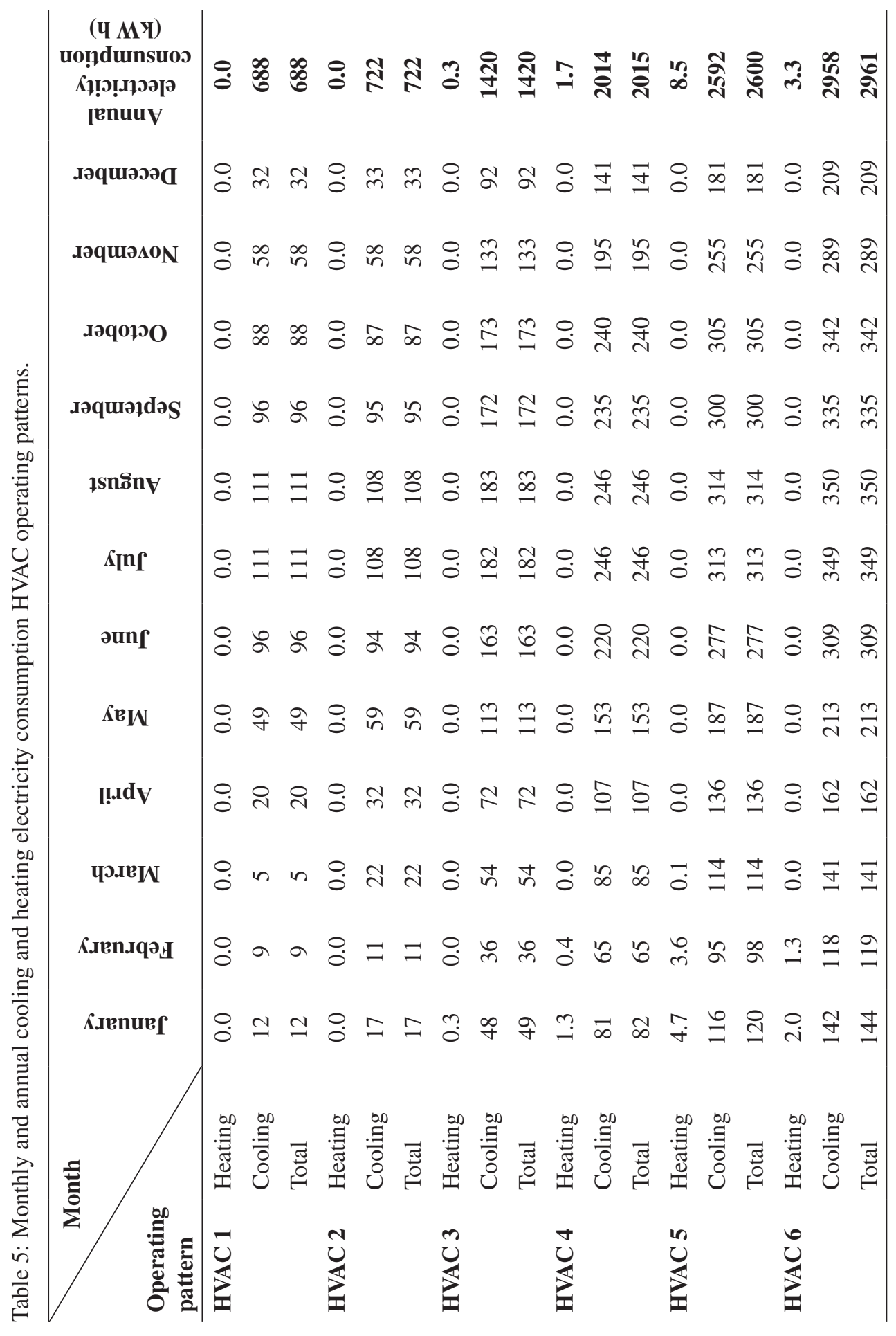




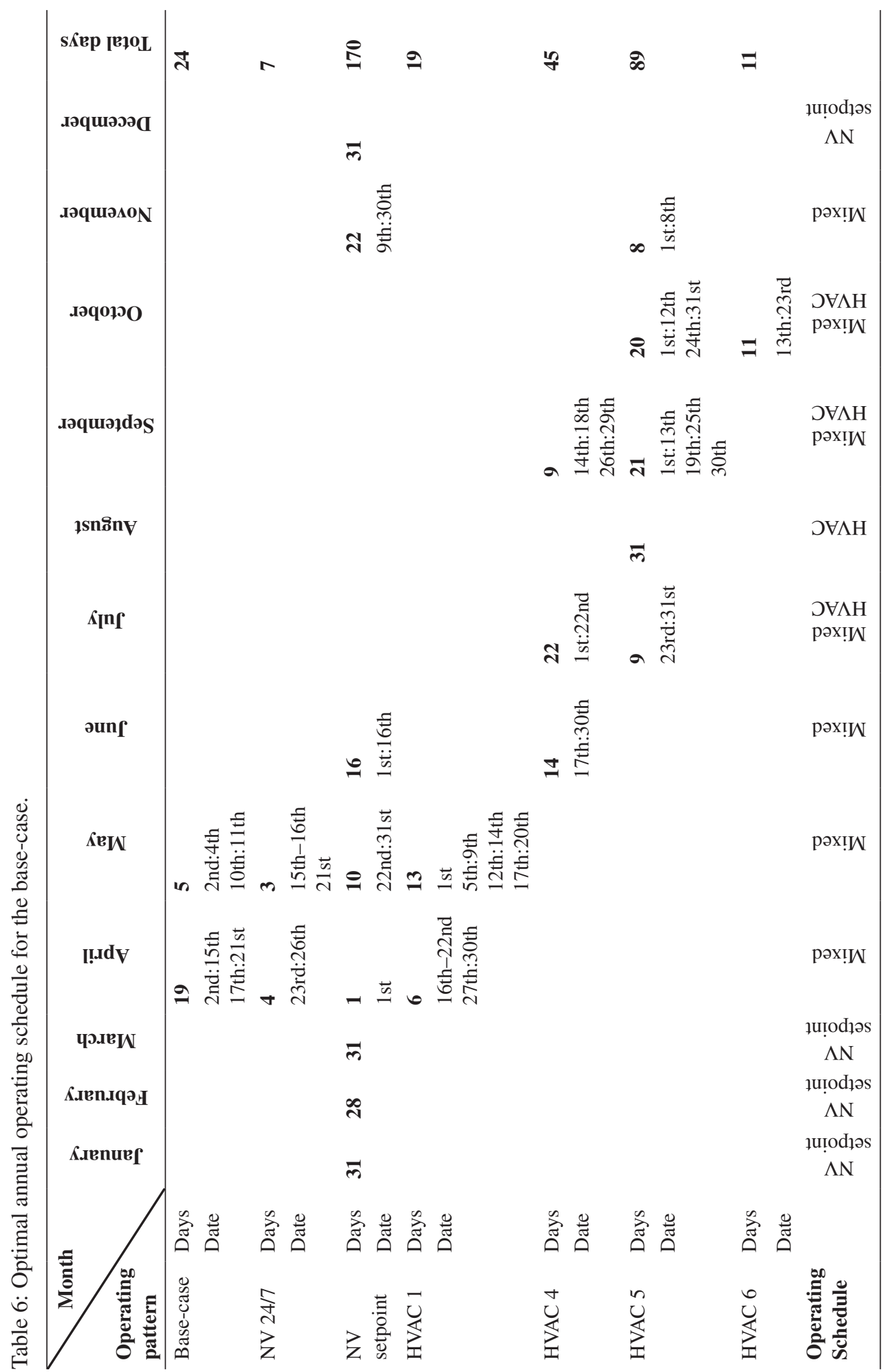




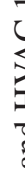

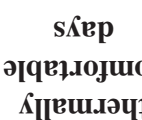
Jo $\cdot 0 \mathrm{~N}$

uọ̣dunsuos ก!ฺฺว Ienuuy

.әфшәวә

.әqшәхоN

งәqоџ๐о

. .әquәңdəs

วงกถึกท

K[nก

aunf

S

I!.MdV

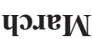

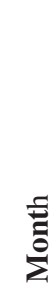

\begin{tabular}{|l}
\hline \\
\hline
\end{tabular}

чMY

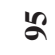

$\stackrel{\varrho}{\varrho}$

ติ

I

$\stackrel{4}{\pi}$

ț

זس/पMY

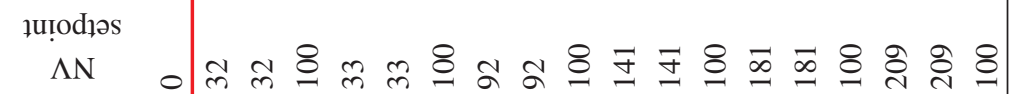

pəx!W

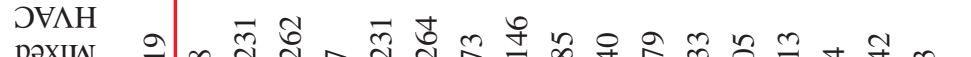

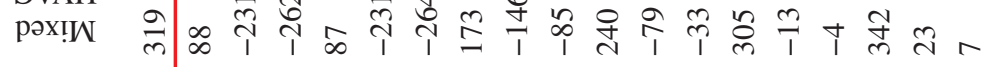

PəX!H

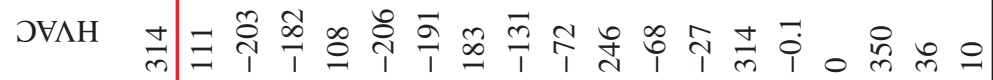

рәХ!N

pəx!W

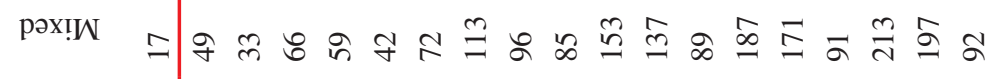

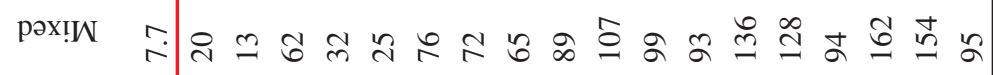

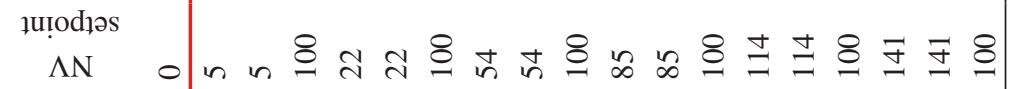

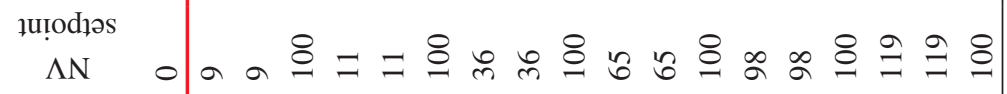

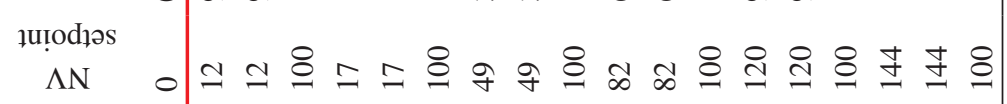

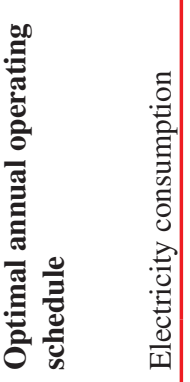

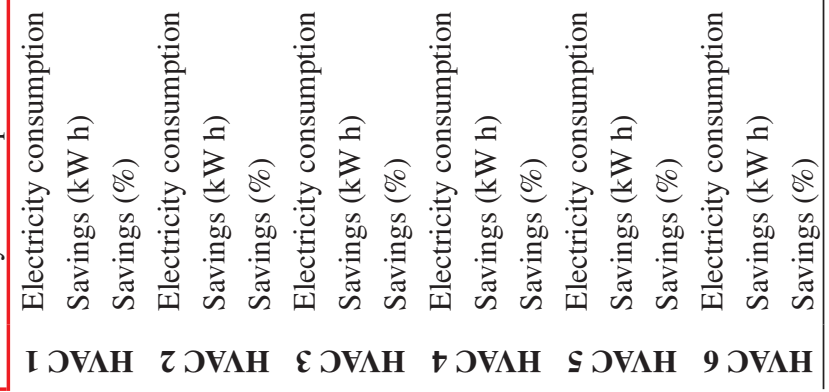


comfort for 365 days and save electrical energy at the same time, each month has one or more operating patterns, as shown in Table 6.

The optimal annual operating schedule has seven operating patterns out of nine. HVAC 2 and 3 are excluded because there is a more energy-efficient operating pattern to be used, which achieves thermal comfort. The operating schedule of any month uses either NV setpoint, HVAC, mixed, or mixed HVAC, where mixed is an integration among base-case or/and NV24/7 or/and NV setpoint and any of the $\operatorname{HVAC}(1,4,5$, or 6$)$ and mixed HVAC is an integration among any of the HVAC operating patterns (1, 4, 5, and 6). NV setpoint is used in the schedule in the months from January till March, and December. One or four days in each of these months have daily average PMV values of -0.6 , which have only 0.5 or 1 discomfort hour; therefore, these days are considered thermally comfortable and the whole months are considered thermally comfortable. The mixed schedule is used in April, May, June, and November, while mixed HVAC is used in July, September, and October. August is the only month that uses HVAC.

The base-case, NV 24/7, and NV setpoint operating patterns are used for 24, 7, and 170 days, respectively; all represent around 55\% of the year days, while HVAC 1, 4, 5, and 6 are used for 19, 45, 89, and 11 days, respectively.

Table 7 shows the monthly and annual electricity consumption of the optimal operating schedule and each of the HVAC operating patterns; electrical energy savings are calculated by comparison with the optimal operating schedule. The table also shows the number of thermally comfortable days of each HVAC operating pattern. The optimal annual operating schedule (highlighted in red borders in Table 7) consumes annually $1388 \mathrm{~kW} \mathrm{~h}$ and achieves 365 thermally comfortable days a year. The highest annual energy consumption is for HVAC 6 at $2961 \mathrm{~kW}$ h with only 164 thermally comfortable days, while the lowest is for HVAC 1 with $688 \mathrm{~kW} \mathrm{~h}$ and 95 days. HVAC 1 and 2 consume less electrical energy (688 and $722 \mathrm{~kW}$ $\mathrm{h}$, respectively) than the optimal annual operating schedule while only achieving 95 and 103 thermally comfortable days, respectively. HVAC 5 achieves the highest number of thermally comfortable days with 235 of all HVAC operating patterns and consumes $2600 \mathrm{~kW}$ h electrical energy annually. Using the optimal annual operating schedule can save $31 \%, 47 \%$, and $53 \%$ of the total cooling and heating electrical energy annually, when compared to HVAC 4, 5 , and 6 that only achieve 194, 235, and 164 thermally comfortable days, respectively.

\section{CONCLUSION AND RECOMMENDATIONS}

The main focus of this work is the effective utilization of natural ventilation in heritage buildings in the temperate-humid climate. This study aimed to propose an approach in the form of a design strategy to develop an optimal annual operating schedule targeting the best operating pattern/s for each month to save electrical energy, while achieving users' thermal comfort in heritage buildings. The proposed approach can be considered as a preliminary stage of energy-efficient retrofitting of heritage buildings in Alexandria, Egypt. The optimal annual operating schedule was applied to a room in a typical heritage building in the central district of Alexandria city to examine its feasibility in achieving thermal comfort and saving energy. The results showed that users' thermal comfort could be achieved while significantly saving electrical energy by using natural ventilation, as it allowed the space to be naturally cooled and heated according to the specified month.

Using the developed optimal annual operating schedule can save up to $47 \%$ of the total cooling and heating electrical energy annually, while achieving thermal comfort for all days of the year. The thermally comfortable days are achieved by using controlled natural 
ventilation in the winter months, while using HVAC cooling with different temperature setpoints in the summer months. Natural ventilation alone, whether 24/7 or controlled, can be used for $48 \%$ (177 days) of the thermally comfortable days of the year, saving up to $20 \%$ of cooling and heating electrical energy annually. Moreover, experimenting different cooling temperature setpoints is essential to improve the indoor OPT and save electrical energy while achieving thermal comfort. However, lowering the cooling temperature setpoint in HVAC systems has to be carefully done as it may have unnecessary heating electricity consumption in the winter months in the south-oriented rooms in heritage buildings.

The developed optimal annual operating schedule resulted in an adjusted base-case, which is an adaptive user behavior in controlling the surrounding environment to feel thermally comfortable, which is similar to the actual energy validation model. This adjusted base-case can also be used in evaluating the retrofitting scenarios for energy-efficient heritage buildings in the temperate-humid climate, which is the next stage of this work. Also, it could be used to study the impact of climate change on the savings of energy consumption in heritage buildings, as it is significantly essential to test the impact of the outdoor weather change on the energy consumption of the HVAC system in buildings over time.

\section{ACKNOWLEDGMENTS}

The authors would like to thank the Egyptian Ministry of Higher Education (MoHE), Egypt-Japan University of Science and Technology (E-JUST), and BEEP project for supporting this work.

\section{REFERENCES}

[1] Goal 11:Sustainable cities and communities, United Nations Development Programme, online. http://www.undp.org/content/undp/en/home/sustainable-development-goals/ goal-11-sustainable-cities-and-communities.html. Accessed on: 27 June 2020.

[2] Green buildings must do more in fixing climate emergency, online, www.eco-business. com/opinion/green-buildings-must-do-more-in-fixing-climate-emergency/. Accessed on: 12 July 2020.

[3] Egypt Vision 2030, Egyptian Ministry of Communications and Information Technology, online, http://mcit.gov.eg/Publication/Publication_Summary/1020/. Accessed on: 16 July 2020.

[4] Zhou, C., Wang, Z., Chen, Q., Jiang, Y. \& Pei, J., Design optimization and field demonstration of natural ventilation for high-rise residential buildings. Energy and Buildings, 82, pp. 457-465, 2014. https://doi.org/10.1016/j.enbuild.2014.06.036

[5] Exner, D., Larcher, M., Belleri, A., Troi, A. \& Haas, F., The 'Waaghaus ' of Bolzano Energy efficiency, hygrothermal risk and ventilation strategy. Proceedings of the 3rd International Conference on Energy Efficiency in Historic Buildings, pp. 135-144, 2018.

[6] Taher, A.K., Prizeman O., Gomaa, B. \& Lannon, S., Case study assessment for natural ventilation performance of heritage buildings in the Mediterranean city of Alexandria (Egypt). IOP Conference Series: Materials Science and Engineering, 609(3), 2019. doi:10.1088/1757-899X/609/3/032012.

[7] Thravalou, S., Philokyprou, M. \& Michael, A., Natural ventilation performance of heritage buildings in the Mediterranean climate, The case of a two-storey urban traditional dwelling in Nicosia. Proceedings of 9Th Windsor Conference: Making Comfort Relevant, pp. 328-339, 2016. 
[8] Nunes de Freitas, P. \& Guedes, M.C., The use of windows as environmental control in 'Baixa Pombalina's' heritage buildings. Renewable Energy, 73, pp. 92-98, 2015. doi: 10.1016/j.renene.2014.08.029.

[9] Dabaieh, M., Wanas, O., Hegazy, M.A. \& Johansson, E., Reducing cooling demands in a hot dry climate: A simulation study for non-insulated passive cool roof thermal performance in residential buildings. Energy and Buildings, 89, pp. 142-152, 2015. doi: 10.1016/j.enbuild.2014.12.034.

[10] Fathy, H., Natural Energy and Vernacular Architecture, United Nations University Press, 2009.

[11] American Society of Heating, Refrigerating \& Air-Conditioning Engineers (ASHRAE), Standard-55: thermal environmental conditions for human occupancy, 7, 2017.

[12] American Society of Heating, Refrigerating \& Air-Conditioning Engineers (ASHRAE), Standard 62.1-2016: Ventilation for acceptable indoor air quality, 2016. 